\title{
Review: continuous caregiver support during labour has beneficial maternal and infant outcomes
}

\author{
Hodnett ED. Caregiver support for women during childbirth. Cochrane Database Syst Rev 2002;(1):CD000199 (latest \\ version 21 Aug 2001).

\section{QUESTION: In women in labour, does continuous support by health professionals or lay people have beneficial maternal and infant outcomes?}

\section{Data sources}

Studies were identified by using the search strategy developed for the Cochrane Pregnancy and Childbirth Group, which included searching Medline, the Cochrane CENTRAL and Controlled Trials Registers, conference proceedings, and handsearching 38 relevant journal titles.

\section{Study selection}

Studies were selected if they were randomised controlled trials that compared continuous labour support by a professional (nurse or midwife) or lay person with usual care for women in labour in hospital delivery wards.

\section{Data extraction}

Data were extracted on country in which the study was done, hospital policy concerning labour accompaniment, caregiver experience and qualifications, timing and duration of support, methodological quality, and outcomes. Outcomes included need for pain medication, medical interventions, type of delivery, Apgar score, breast feeding, postpartum depression, and length of labour.

\section{Main results}

14 trials (5020 women) met the selection criteria. Continuous support reduced the need for pain medication during labour, operative vaginal delivery, caesarean delivery, and 5 minute Apgar scores $<7$ (table). Caregiver support also increased the likelihood of fully breast feeding 4-6 weeks after delivery (2 trials) and showed more favourable maternal views of the childbirth experience ( 6 trials). Of 2 trials that assessed postpartum anxiety and self esteem, 1 trial showed better results with caregiver support and 1 trial showed no difference. Length of labour was slightly shorter in caregiver support groups (9 trials) $(-0.32 \mathrm{~h}, 95 \%$ CI -0.54 to -0.09 ). When trials were grouped by whether hospitals allowed accompaniment by husbands, partners, or other family members during labour (7 trials) and those that allowed no additional support people (7 trials), the results were consistent.

\section{Conclusion}

In women in labour, continuous support by nurses, midwives, or lay people has beneficial maternal and infant outcomes and has no associated risks.

Caregiver support $v$ usual care for women in labour*

\begin{tabular}{|c|c|c|c|c|c|}
\hline \multirow[b]{2}{*}{ Outcomes } & \multirow[b]{2}{*}{$\begin{array}{l}\text { Number of } \\
\text { trials }\end{array}$} & \multicolumn{2}{|c|}{ Weighted event rates } & \multirow[b]{2}{*}{ RRR $(95 \% \mathrm{Cl})$} & \multirow[b]{2}{*}{ NNT (Cl) } \\
\hline & & $\begin{array}{l}\text { Caregiver } \\
\text { support }\end{array}$ & $\begin{array}{l}\text { Usual } \\
\text { care }\end{array}$ & & \\
\hline $\begin{array}{l}\text { Any intrapartum } \\
\text { analgesia }\end{array}$ & 12 & $45 \%$ & $51 \%$ & $13 \%$ (8 to 17$)$ & 15 (11 to 25$)$ \\
\hline Operative vaginal delivery & 13 & $14 \%$ & $17 \%$ & $19 \%$ (8 to 28 ) & 31 (19 to 77 ) \\
\hline Caesarean delivery & 14 & $11 \%$ & $13 \%$ & $20 \%$ (7 to 32$)$ & 38 (23 to 112 ) \\
\hline $\begin{array}{l}\text { Apgar score }<7 \text { at } \\
5 \text { minutes }\end{array}$ & 7 & $1.1 \%$ & $2.3 \%$ & $50 \%(11$ to 71$)$ & 84 (48 to 500$)$ \\
\hline
\end{tabular}

Thornton JG, Lilford RJ. Active management of labour: current knowledge and research issues. BMJ 1994;309:366-9.

2 Corbett CA, Callister LC. Nursing support during labour. Clin Nurs Res 2000;9:70-83. 